\title{
Meningkatkan hasil belajar peserta didik dengan menggunakan E-modul berbasis Flipbook (E-modul otomatisasi tata kelola kepegawaian yang bermanfaat di era Covid-19)
}

\author{
Siti Khoiriyah, Heri Pratikto* \\ Universitas Negeri Malang, Jl. Semarang No. 5 Malang, Jawa Timur, Indonesia \\ *Penulis korespondensi, Surel: heri.pratikto.fe@um.ac.id
}

Paper received: 7-6-2021; revised: 21-6-2021; accepted: 28-6-2021

\begin{abstract}
Abstrak
Penggunaan bahan ajar di SMK Negeri 2 Blitar yang belum dimanfaatkan dalam kegiatan belajar mengajar secara maksimal membuat proses pembelajaran menjadi monoton dan membosankan. Sehingga hasil belajar peserta didik masih sangat bervariasi. Tidak semua hasil belajar peserta didik kelas XI-OTKP di SMK Negeri 2 Blitar tersebut memasuki nilai tinggi atau baik apalagi di masa pandemi ini. Oleh karena itu peneliti melakukan penelitian dan pengembangan bertujuan untuk menghasilkan bahan ajar E-modul berbasis Flipbook untuk meningkatkan hasil belajar peserta didik kelas XI-OTKP SMK Negeri 2 Blitar. Keunikan dari produk ini adalah terdapat audio penjelasan mengenai point di dalam materi yang dianggap sulit oleh peserta didik. Jenis penelitian dan pengembangan ini menggunakan model Research and Development Borg and Gall yang telah dimodifikasi. Subjek dalam penelitian ini terdiri dari ahli media dan ahli materi sebagai validator ahli, 6 peserta didik kelas XI-OTKP di SMK Negeri 2 Blitar sebagai validator pengguna, serta subjek uji coba kelompok besar. Data yang diperoleh berupa data kualitatif dari lembar validasi ahli materi, ahli media, dan uji coba kelompok kecil yang berupa kritik dan saran, selain itu terdapat data kualitatif yang diperoleh dari perhitungan skor dari pada lembar validasi yang yang diberikan kepada ahli materi, ahli media, dan kelompok kecil, data kuantitatif juga didapat dari hasil nilai kognitif dari kelas eksperimen dan kelas kontrol. Berdasarkan data yang telah diperoleh maka teknik analisis data yang digunakan adalah teknik analisis data kualitatif dan kuantitatif. Data posttest kelas eksperimen dan kontrol dianalisis dengan analisis persentase. Hasil validasi dan uji coba menunjukkan bahwa Emodul berbasis Flipbook telah sesuai dengan peruntukannya, tujuan pembelajaran, materi pembelajaran, dan dapat digunakan untuk menunjang kegiatan pembelajaran serta mampu meningkatkan hasil belajar peserta didik. Hal ini dapat dilihat dari hasil validasi ahli materi sebesar 100\%, hasil validasi ahli media sebesar 93,33\%, dan hasil uji coba produk kelompok kecil sebesar 93,33\%.
\end{abstract}

Kata kunci: e-modul; flipbook; otomatisasi tata kelola kepegawaian; hasil belajar

\section{Pendahuluan}

Hasil belajar di dalam pembelajaran berperan sangatlah penting karena keberhasilan peserta didik yang dilakukan dalam kegiatan belajar mengajar dapat dilihat dari hasil belajarnya. Hasil belajar adalah pola-pola perbuatan, nilai-nilai, pengertian-pengertian, sikapsikap, apresiasi dan keterampilan (Widodo \& Widayanti, 2014). Hasil belajar juga merupakan hasil yang dicapai oleh peserta didik setelah melakukan kegiatan belajar dan hasil belajar akan terus mengalami perubahan dan perkembangan (Lestari, 2015). Peserta didik berusaha mendapatkan hasil belajar yang terbaik untuk mencapai prestasi yang baik. Hasil belajar peserta didik tidak hanya dilihat dari nilai akademiknya di sekolah tetapi juga dilihat dari perubahan-perubahan dalam diri peserta didik tersebut, karena dalam KBM (Kegiatan Belajar Mengajar) peserta didik mengalami proses belajar mengajar sebagai proses perubahan yang

This work is licensed under a Creative Commons Attribution-ShareAlike 4.0 International License. 
ada didalam diri akibat pengalaman yang diperoleh peserta didik saat berinteraksi dengan lingkungannya (Sudjana, 2013).

Didasarkan pada hasil studi pendahuluan melalui wawancara kepada Guru Mata Pelajaran Otomatisasi Tata kelola Kepegawaian di SMK Negeri 2 Blitar pada tanggal 02 September, hasil belajar peserta didik kelas XI OTKP masih sangat bervariasi. Sebanyak 50\% peserta didik kelas XI OTKP di SMKN 2 Blitar mendapatkan nilai di bawah KKM. Beberapa hasil belajar peserta didik yang kurang memuaskan dikarenakan pada saat pandemi peserta didik belajar secara online sehingga peserta didik yang tidak memiliki sumber belajar hanya mendapatkan materi dari video pembelajaran yang disampaikan oleh guru dengan durasi kurang dari 15 menit.Faktor-faktor yang menyebabkan hasil belajar peserta didik sangat bervariasi antara lain dari pendidik/guru, peserta didik, dan lainnya (Nurhasanah \& Sobandi, 2016). Faktor dari guru merupakan tentang bagaimana guru dalam menyampaikan materi kepada peserta didik, juga tentang ketepatan guru dalam memilih suatu strategi dalam menyampaikan materi. Namun demikian, faktor dari diri peserta didik juga mempengaruhi keberhasilan suatu pembelajaran. Faktor dari diri siswa meliputi minat belajar dan motivasi. faktor lainnya adalah faktor yang berasal dari luar diri siswa dan guru, misalnya fasilitas belajar, situasi kelas, dukungan orang tua, lingkungan belajar, dan sebagainya.

Media pembelajaran menurut (Rusman, 2013) adalah alat atau bentuk stimulus yang berfungsi untuk menyampaikan pesan pembelajaran. Bentuk-bentuk stimulus bisa dipergunakan sebagai media diantaranya adalah hubungan atau interaksi manusia, realita, gambar bergerak atau tidak, tulisan, dan suara yang direkam. Sedangkan bahan ajar adalah sebuah buku yang ditulis dengan tujuan agar siswa belajar mandiri atau tanpa bantuan guru (Wahyuni, 2015). Di era sekarang banyak sekali bahan ajar elektronik yang menyajikan dalam bentuk video, animasi, instruksi dengan sistem komunikasi interaktif stimulus respon serta sistematis sesuai dengan kurikulum yang berlaku di sekolah seperti e-Modul, E-Book, dls.

Dalam dunia pendidikan pemanfaatan teknologi informasi dan komunikasi yang digunakan di dalam proses kegiatan pembelajaran dikenal dengan istilah e-learning. E-learning merujuk pada pembelajaran dengan menggunakan jasa perangkat elektronika (Supardi, 2013). Salah satu bentuk bahan ajar dalam format digital atau elektronik tersebut adalah $e$-module. Emodule adalah suatu modul yang dikemas dalam bentuk elektronik dengan lebih interaktif dan disusun secara sistematis (Sugihartini \& Jayanta, 2017). Salah satu aplikasi yang dapat digunakan untuk software e-module adalah Flipbook. Flipbook merupakan aplikasi yang digunakan untuk melakukan desain dan membangun perangkat pembelajaran (E. Wibowo \& Pratiwi, 2018); (Wijayanto \& Zuhri, 2014); (Ricu Sidiq \& Najuah, 2020); (Hayati et al., 2015). Proyek yang dibangun dengan Flipbook bisa terdiri dari atas animasi, musik, tema, gambar, audio, video, atau efek-efek lainnya. Beberapa aplikasi bantuan akan sangat memungkinkan untuk dimanfaatkan sebagai sarana pengembangan bahan ajar.

Pengembangan E-Modul berbasis Flipbook yang akan dilakukan peneliti seperti yang diuraikan di atas mengacu pada beberapa penelitian sebelumnya yaitu oleh (Fitri, 2020); (Fonda \& Sumargiyani, 2018); (Linda et al., 2018) didapatkan hasil bahwa bahan ajar berbasis Kvisoft Flipbook dapat meningkatkan motivasi belajar peserta didik. Penelitian juga dilakukan oleh (Muslikhah et al., 2016); (M. H. Wibowo \& Purnamasari, 2019); (Oktavira \& Pahlevi, 2019) hasil penelitian menunjukkan bahwa bahan ajar berbantuan Flipbook dapat mempengaruhi hasil belajar peserta didik. Artinya pemanfaatan bahan ajar yang interaktif dalam proses 
belajar akan memperjelas bahan pengajaran, sehingga lebih jelas maknanya dan dapat dipahami oleh peserta didik.

Berdasarkan pemaparan mengenai pentingnya bahan ajar di dalam proses belajar mengajar pada mata pelajaran Otomatisasi Tata Kelola Kepegawaian, serta pentingnya meningkatkan hasil belajar peserta didik, maka peneliti melakukan pengembangan E-modul berbasis Flipbook pada mata pelajaran Otomatisasi Tata Kelola Kepegawaian untuk meningkatkan hasil belajar peserta didik.

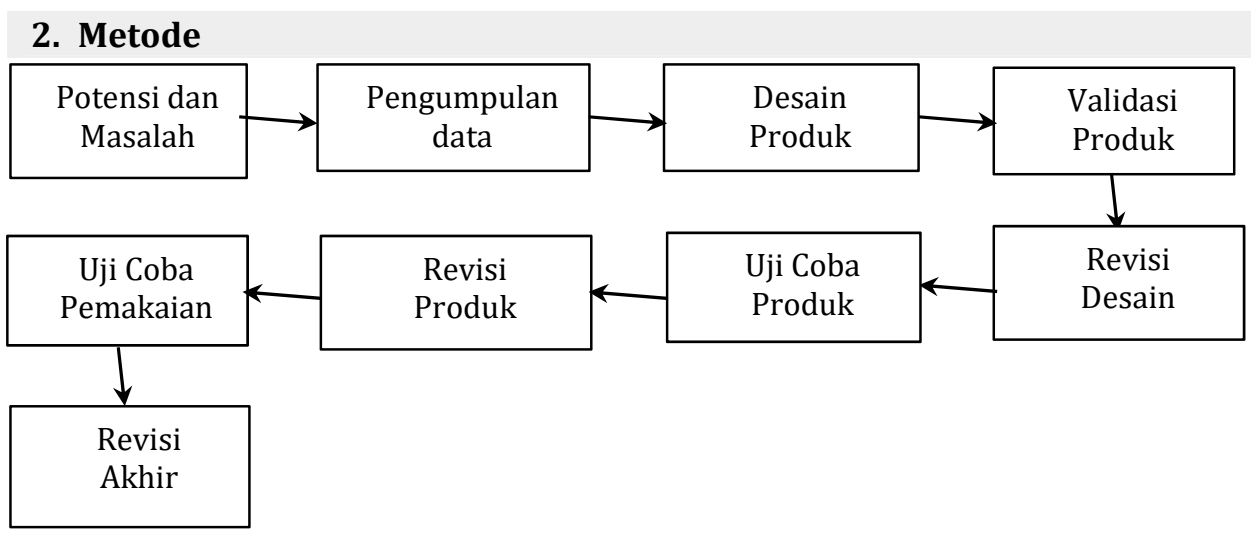

Gambar 1. Langkah-langkah penelitian
Sumber: Modifikasi Langkah-Langkah Pengembangan Borg and Gall (Sugiyono, 2015; 409)

Penelitian ini menggunakan pendekatan penelitian dan pengembangan (Research and Development $/ R \& D$ ) dari Borg and Gall. Metode Penelitian dan Pengembangan merupakan metode penelitian dengan tujuan utama adalah untuk menghasilkan produk tertentu, dan menguji efektivitas dari produk tersebut (Sugiyono, 2011).

Langkah pertama, peneliti mengumpulkan informasi terkait permasalahan dan potensi pada mata pelajaran Otomatisasi Tata Kelola Kepegawaian. Langkah kedua, peneliti menentukan ahli validasi, kelompok kecil, kelas eksperimen dan kelas control, serta bahanbahan pendukung untuk mengembangkan materi. Langkah ketiga, peneliti membuat desain bahan ajar E-modul berbasis Flipbook. Langkah keempat, produk peneliti diuji layakan oleh para validator, yakni satu ahli media dan satu ahli materi. Langkah kelima, produk yang telah divalidasi direvisi berdasarkan kritik dan saran baik secara lisan maupun tulisan yang tertera pada lembar angket penilaian ahli materi dan ahli media. Langkah keenam, produk yang telah direvisi diujicobakan pada 6 siswa kelas XI-OTKP2 di SMK Negeri 2 Blitar. Langkah ketujuh, produk yang telah diujicobakan pada kelompok kecil direvisi sesuai masukan-masukan peserta didik baik secara lisan maupun tulisan yang tertera pada lembar hasil angket uji coba kelompok kecil. Langkah kedelapan, produk yang telah direvisi kemudian diujicobakan pada kelompok besar yang melibatkan 33 siswa kelas XI-OTKP 3 selaku kelas eksperimen dan 33 siswa kelas XI-OTKP 1 selaku kelas control. Langkah kesembilan, peneliti melakukan pengemasan produk dalam bentuk CD (Compact Disk).

Data yang dihasilkan pada penelitian ini meliputi data kualitatif dan data kuantitatif, dimana data kualitatif didapatkan melalui penarikan kesimpulan berdasarkan pendapat secara umum, saran, dan kritik dari ahli materi, ahli media, dan 6 siswa uji coba kelompok kecil. Sedangkan data kuantitatif terdiri dari data hasil validasi ahli materi, data hasil validasi media, 
data hasil uji coba kelompok kecil, dan hasil belajar peserta didik. Data hasil validasi ahli materi, ahli media, uji coba kelompok kecil, dan hasil belajar dianalisis menggunakan metode deskriptif persentase untuk menunjukkan tingkat kelayakan E-Modul berbasis Flipbook.

\section{Hasil dan Pembahasan}

\subsection{Hasil Pengembangan}

Produk yang dihasilkan dalam penelitian dan pengembangan ini adalah E-Modul berbasis Flipbook pada mata pelajaran Otomatisasi Tata Kelola Kepegawaian (E-MOGA) KD 3.8 Menerapkan Pengembangan Kari Pegawai dan KD 4.8 Mengelola Pengembangan Karir Pegawai. E-MOGA dapat dioperasikan melalui Laptop/PC dengan format .exe dan Handphone Android dengan format app serta disertai dengan audio penjelasan dalam bagian materi pembelajaran. Dalam E-MOGA, secara umum, polanya terbagi menjadi 5, yaitu pendahuluan, materi pembelajaran, rangkuman, soal evaluasi, dan tentang penulis. Berikut ini gambar 2 halaman tampilan pendahuluan.

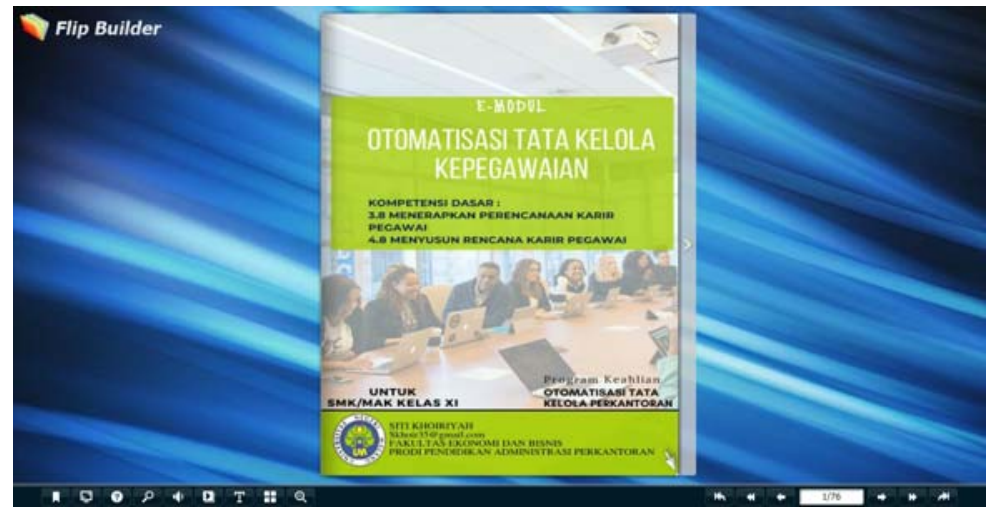

Gambar 2. Tampilan Cover E-Modul Otomatisasi Tata Kelola Kepegawaian

Cover pada E-Modul Otomatisasi Tata Kelola Kepegawaian didesain berdasarkan nama mata pelajaran, kompetensi dasar dan juga peruntukkan kelas. Cover E-Modul Otomatisasi Tata Kelola Kepegawaian didesain dengan berbantuan aplikasi android yaitu Canva. Pada Cover ini juga diberikan gambar sebuah kegiatan pegawai perkantoran yang didesain lebih pudar dari nama Mata pelajaran dan kompetensi dasar, hal ini menunjukkan bahwa adanya pembahasan mengenai pegawai perkantoran. 


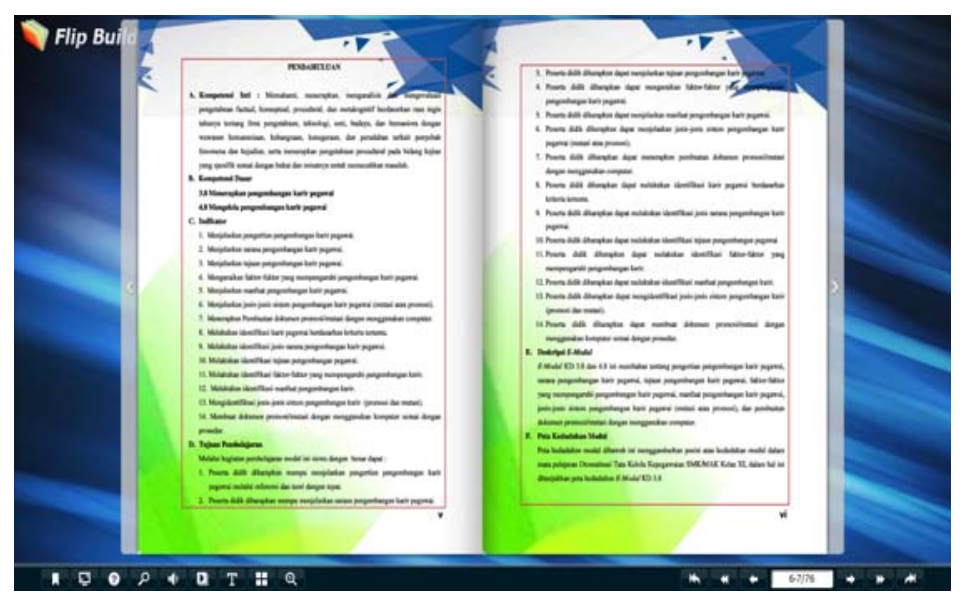

Gambar 3. Tampilan Pendahuluan E-Modul Otomatisasi Tata Kelola Kepegawaian

Pada bagian pendahuluan dalam E-Modul Otomatisasi Tata Kelola Kepegawaian terdiri dari Kompetensi Inti dan Kompetensi Dasar, indikator, tujuan pembelajaran, deskripsi EModul Otomatisasi Tata Kelola Kepegawaian, peta kedudukan e-modul, petunjuk penggunaan E-Modul Otomatisasi Tata Kelola Kepegawaian, tujuan akhir. Hal ini dimaksudkan untuk memberikan gambaran mengenai isi dari E-Modul Otomatisasi Tata Kelola Kepegawaian.

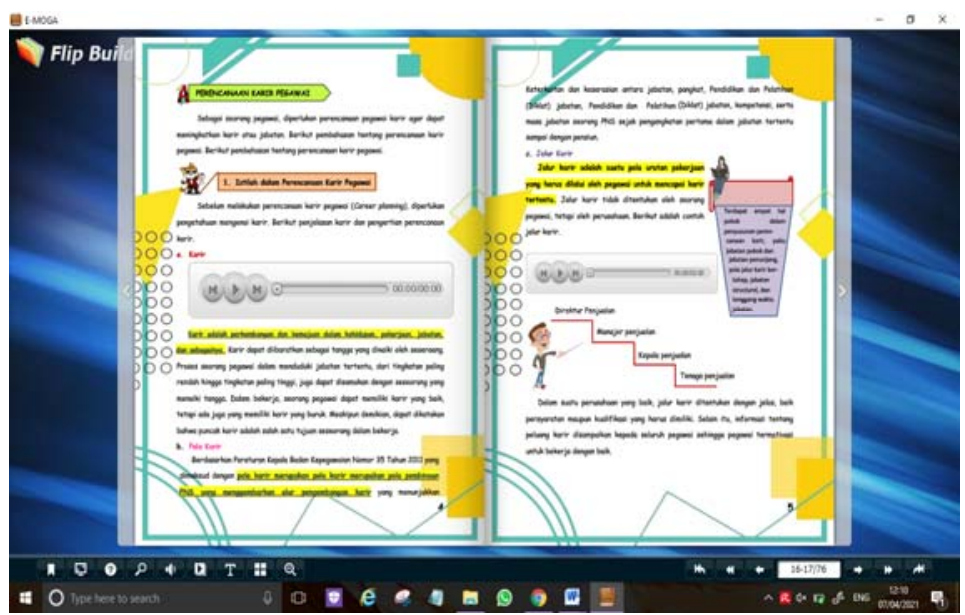

Gambar 4. Tampilan Materi Pembelajaran E-Modul Otomatisasi Tata Kelola Kepegawaian

Pada bagian materi pembelajaran terdiri dari 4 sub-bab yaitu, perencanaan karir pegawai, pengembangan karir, pola karir, dan pembuatan dokumen perencanaan, pengembangan dan pola karir. Dalam upaya untuk lebih memahamkan peserta didik mengenai materi ini, maka pada materi pembelajaran E-Modul Otomatisasi Tata Kelola Kepegawaian terdapat audio penjelasan yang menjelaskan mengenai point yang dianggap sulit oleh peserta didik, dan juga beberapa jendela teks yang menekankan poin penting mengenai materi yang dibahas. 


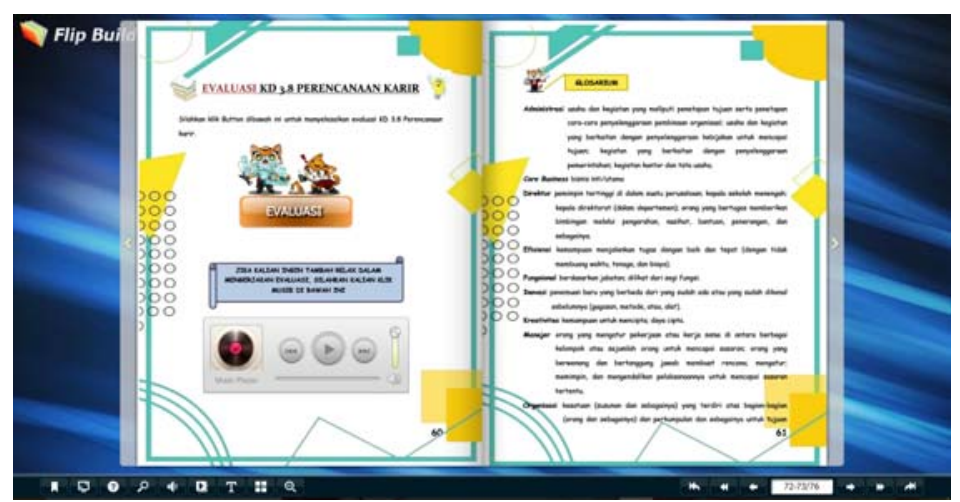

Gambar 5. Tampilan Halaman Evaluasi E-Modul Otomatisasi Tata Kelola Kepegawaian

Pada bagian evaluasi didesain dengan menambahkan musik, agar peserta lebih rileks dalam mengerjakan soal evaluasi, di dalam soal evaluasi ini juga peserta didik dapat mengetahui secara otomatis jawaban benar atau salah. Dan di akhir evaluasi peserta didik akan mengetahui nilai dari pengerjaan evaluasi tersebut.

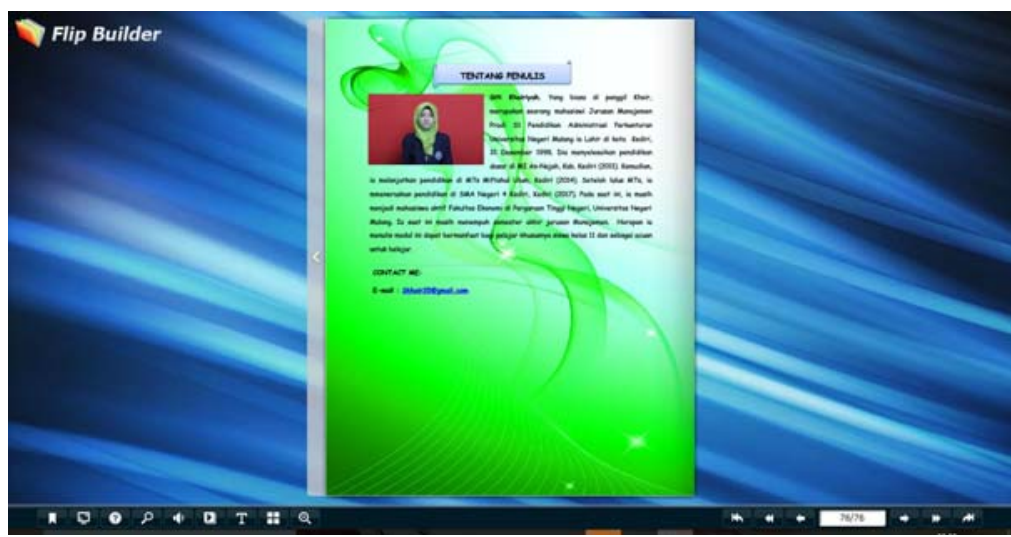

Gambar 6. Profil Penulis

Profil penulis ditambahkan pada akhir halaman agar peserta didik dan pendidik yang mengalami kesulitan atau kendala ketika mempelajari E-Modul Otomatisasi Tata Kelola Kepegawaian dapat menghubungi penulis melalui email yang dicantumkan. Selain itu, peserta didik dan pendidik juga dapat memberikan saran untuk perbaikan kepada penulis.

Selanjutnya E-MOGA yang sudah selesai di desain maka dilakukan validasi untuk mengetahui kelayakan E-modul sebagai bahan ajar. Kelayakan E-MOGA berdasarkan ahli materi dan ahli media berdasarkan aspek yang telah tercapai (Ernawati \& Sukardiyono, 2017). Aspek yang dinilai oleh ahli materi terkait isi dari bahan ajar (Wulandari \& Purwanto, 2017) seperti, isi materi, evaluasi, bahasa, kegrafikaan, dan keefektifan bahan ajar . Sedangkan, aspek yang dinilai oleh ahli media terkait kelayakan produk (Amaliyah \& Puspasari, 2018) seperti, kelayakan penyajian materi, penyajian bahan ajar, dan kelayakan video dan audio.

\subsection{Tinjauan dari Ahli Materi}

Data kelayakan E-Modul Otomatisasi Tata Kelola Kepegawaian oleh ahli materi berupa perhitungan persentase aspek penilaian disajikan pada Tabel 1. 
Tabel 1. Data hasil validasi ahli materi.

\begin{tabular}{llcl}
\hline Aspek Penilaian & $\begin{array}{c}\text { Jumlah Keseluruhan } \\
\text { Nilai Ahli Materi }\end{array}$ & $\begin{array}{c}\text { Persentase } \\
\text { (\%) }\end{array}$ & Kriteria \\
\hline Kelayakan materi & 30 & $100 \%$ & Sangat valid \\
Kelayakan evaluasi & 20 & $100 \%$ & Sangat valid \\
Kelayakan bahasa & 15 & $100 \%$ & Sangat valid \\
Kelayakan kegrafikan & 20 & $100 \%$ & Sangat valid \\
Keefektifan & 25 & $100 \%$ & Sangat valid \\
\multicolumn{1}{l}{ penggunaan media } & & & \\
\hline
\end{tabular}

Validator materi merupakan guru mata pelajaran Otomatisasi Tata Kelola Kepegawaian di SMK Negeri 2 Blitar yaitu Ibu Siti Meimunah, S.Pd. M.Pd. Validasi ahli materi dilakukan untuk mengkaji dan menilai kelayakan dan ketepatan materi E-Modul Otomatisasi Tata Kelola Kepegawaian. Validasi materi dilakukan dengan pengisian angket oleh validator. Angket terdiri 5 aspek penilaian yaitu kelayakan materi, kelayakan evaluasi, kelayakan bahasa, kelayakan kegrafikan, dan keefektifan penggunaan media dengan skala penilaian 1-5. Ahli materi juga memberikan catatan dan saran untuk perbaikan e-modul Otomatisasi Tata Kelola Kepegawaian.

Tabel 1 menunjukkan bahwa hasil persentase dari semua aspek penilaian diperoleh data sebesar 100\%, hal ini dikarenakan menurut ahli materi e-modul Otomatisasi Tata Kelola Kepegawaian sudah memenuhi semua aspek penilaian E-Modul dan dirancang sesuai dengan karakteristik serta kebutuhan peserta didik. Sehingga berdasarkan klasifikasi nilai tersebut berada pada rentang 85\% - 100\% yang berarti bahwa E-modul Otomatisasi Tata Kelola Kepegawaian dalam kualifikasi sangat valid. Dari hasil tersebut disimpulkan bahwa E-modul Otomatisasi Tata Kelola Kepegawaian berbasis Flipbook valid dan sangat layak untuk diuji cobakan sesuai dengan kritik dan saran ahli materi.

\subsection{Tinjauan dari Ahli Media}

Data kelayakan E-modul Otomatisasi Tata Kelola Kepegawaian oleh ahli media berupa perhitungan persentase aspek penilaian disajikan pada Tabel 2.

Tabel 2. Data hasil validasi ahli media

\begin{tabular}{llcl}
\hline Aspek Penilaian & $\begin{array}{c}\text { Jumlah Keseluruhan } \\
\text { Nilai Ahli Media }\end{array}$ & $\begin{array}{c}\text { Persentase } \\
\text { (\%) }\end{array}$ & Kriteria \\
\hline Penyajian bahan ajar & 19 & $92 \%$ & Sangat valid \\
$\begin{array}{l}\text { Penyajian materi } \\
\begin{array}{l}\text { Penyajian audio dan } \\
\text { video }\end{array}\end{array}$ & 14 & $90 \%$ & Sangat valid \\
\end{tabular}

Table used by permission (CKhoiriyah, Siti. 2021. Data hasil validasi ahli media.

Validator media merupakan dosen Fakultas Ekonomi dan Bisnis Universitas Negeri Malang yaitu Bapak Buyung Adi Dharma, S.AP., M.AP. Validasi ahli media dilakukan untuk mengkaji dan menilai kelayakan E-modul Otomatisasi Tata Kelola Kepegawaian.

Tabel 2 menunjukkan bahwa persentase hasil validasi media sebesar 92\% untuk aspek penilaian penyajian bahan ajar. Pada aspek penilaian penyajian materi diperoleh data sebesar 90\%. Pada aspek penyajian audio dan video diperoleh data sebesar 100\%. Berdasarkan 
kriteria kelayakan pada tabel 2, persentase tersebut pada rentang $85 \%-100 \%$. Hal ini menunjukkan bahwa E-modul Otomatisasi Tata Kelola Kepegawaian masuk dalam kriteria sangat layak untuk diujicobakan. Berdasarkan hasil tersebut maka ditarik kesimpulan bahwa E-modul Otomatisasi Tata Kelola Kepegawaian berbasis Flipbook ini sangat valid dan layak diuji cobakan sesuai dengan kritik dan dilakukan revisi berdasarkan catatan dan saran dari ahli media.

\subsection{Tinjauan dari Uji Coba produk}

Data kelayakan E-modul Otomatisasi Tata Kelola Kepegawaian oleh kelompok kecil berupa perhitungan persentase aspek penilaian disajikan pada Tabel 3.

Tabel 3. Data hasil uji coba produk kelompok kecil

\begin{tabular}{llcl}
\hline Aspek Penilaian & $\begin{array}{c}\text { Jumlah Keseluruhan } \\
\text { Nilai Kelompok Kecil }\end{array}$ & $\begin{array}{c}\text { Persentase } \\
\mathbf{( \% )}\end{array}$ & Kriteria \\
\hline Substansi materi & 87 & $96 \%$ & Sangat valid \\
Desain pembelajaran & 83 & $92 \%$ & Sangat valid \\
Tampilan komunikasi & 84 & $93 \%$ & Sangat valid \\
$\quad$ visual & & $90 \%$ & Sangat valid \\
Pemanfaatan E-Modul & 54 & &
\end{tabular}

Table used by permission @ Khoiriyah, Siti. 2021. Data hasil uji coba produk kelompok kecil.

Uji coba produk dilakukan oleh kelompok kecil yang mana mengambil 6 peserta didik kelas XI OTKP-2 di SMK Negeri 2 Blitar dengan ketentuan 2 peserta didik berkemampuan tinggi, 2 peserta didik berkemampuan sedang, dan 2 peserta didik berkemampuan rendah. Tujuan uji coba produk pada kelompok kecil adalah guna untuk mengetahui dari segi peserta didik apakah E-modul Otomatisasi Tata Kelola Kepegawaian berbasis Flipbook dapat dengan mudah dipahami oleh peserta didik.

Tabel 3 menunjukkan bahwa persentase hasil uji coba produk pada kelompok kecil sebesar 96\% untuk substansi materi, untuk desain pembelajaran 92\%, untuk tampilan komunikasi visual 93\%, dan 90\% untuk pemanfaatan E-Modul. Menurut klasifikasi nilai tersebut berada pada rentang $85 \%-100 \%$ yang berarti E-modul Otomatisasi Tata Kelola Kepegawaian berbasis Flipbook dalam kualifikasi sangat valid. Dari hasil tersebut dapat disimpulkan bahwa E-modul Otomatisasi Tata Kelola Kepegawaian berbasis Flipbook sangat layak digunakan berdasarkan kritik dan dilakukan revisi berdasarkan catatan dan saran dari kelompok kecil mengenai ukuran file E-modul Otomatisasi Tata Kelola Kepegawaian berbasis Flipbook. Selain itu, E-Modul dirancang sesuai dengan karakteristik dan kebutuhan peserta didik, sehingga mereka dapat menggunakan kapan saja dan di mana saja mereka mau (Tim P2M LPPM UNS, 2010).

Adapun penilaian hasil belajar kelas eksperimen dan kelas kontrol berdasarkan posttest yang diberikan pada kelas eksperimen dan kelas kontrol dengan cara melihat rata-rata hasil belajar. Berikut ini disajikan perbandingan rata-rata hasil belajar Kelas eksperimen dan Kelas kontrol dalam Tabel 4. 
Jurnal Ekonomi, Bisnis dan Pendidikan, 1(6), 2021, 526-537

Tabel 4. Perbandingan Rata-Rata Hasil Belajar Kelas Eksperimen dan Kelas Kontrol

\begin{tabular}{lcc}
\hline \multirow{2}{*}{ Rata-Rata } & Kelas Eksperimen & Kelas Kontrol \\
\cline { 2 - 3 } & 91,40 & 76,25
\end{tabular}

Table used by permission (CKhoiriyah, Siti. 2021. Perbandingan rata-rata hasil belajar.

Berdasarkan Tabel 4 diketahui bahwa rata-rata kelas eksperimen adalah 91,40 dan kelas kontrol adalah 76,25. Dengan demikian dapat disimpulkan bahwa terdapat perbedaan yang signifikan antara rata-rata hasil belajar peserta didik pada posttest kelas eksperimen dan kelas kontrol.

Proses koreksi pada hasil belajar evaluasi posttest kelas eksperimen maupun dari kelas kontrol yang telah dilakukan, maka hasil belajar peserta didik yang diperoleh menunjukkan bahwa adanya perbedaan yang signifikan rata-rata hasil belajar antara kelas eksperimen dan kelas kontrol. Rata-rata hasil belajar kelas eksperimen lebih tinggi dibandingkan rata-rata hasil belajar kelas kontrol. Hasil belajar kelas kontrol lebih rendah dibandingkan dengan kelas eksperimen. Dikarenakan ketika kegiatan belajar mengajar, kelas eksperimen menggunakan E-modul berbasis Flipbook, sehingga peserta didik kelas Eksperimen lebih tertarik dan termotivasi untuk belajar. Selain itu, penggunaan E-modul Otomatisasi Tata Kelola Kepegawaian berbasis Flipbook lebih memudahkan kelas eksperimen dalam memahami materi mereka.

Selain itu E-modul Otomatisasi Tata Kelola Kepegawaian berbasis Flipbook ini memiliki beberapa keunggulan, pertama terdapat audio penjelasan yang memudahkan guru dalam menyampaikan materi dalam proses pembelajaran di kelas maupun daring. Hal ini sesuai dengan pernyataan (Nurseto, 2011); (Divayana et al., 2020); (Asrial et al., 2019) bahwa Emodul berbasis Flipbook dibuat untuk memudahkan proses pembelajaran mandiri maupun kelompok serta dapat memberikan motivasi. Selain itu, E-modul Otomatisasi Tata Kelola Kepegawaian berbasis Flipbook membantu peserta didik memahami materi yang disampaikan oleh guru dengan mudah.

Kedua, E-modul Otomatisasi Tata Kelola Kepegawaian berbasis Flipbook sangat mudah dioperasikan baik guru maupun peserta didik melalui Laptop maupun Handphone Android (Sukmawati, 2016); (Meiristanti \& Puspasari, 2020); (Ismiarti \& Nikmah, 2021). Menurut Satyaputra dan Aritonang (Dalam Syahroni et al., 2016) , android adalah sebuah sistem operasi untuk smartphone dan tablet. Sistem operasi dapat diilustrasikan sebagai jembatan antara device dan penggunanya, sehingga pengguna bisa berinteraksi dengan devicenya dan menjalankan aplikasi yang sudah tersedia pada device. Lebih lanjut kelebihan e-modul berbasis Flipbook (Wijayanti et al., 2016); (Sugianto et al., 2013); (Diani \& Hartati, 2018) menyampaikan bahwa kelebihan E-Modul berbasis Flipbook juga diantaranya adalah E-Modul disertai dengan link navigasi yang dapat menciptakan interaktivitas antara pengguna dengan program.

\section{Simpulan}

Penelitian dan pengembangan ini menghasilkan E-Modul berbasis Flipbook untuk peserta didik Kelas XI-OTKP pada mata pelajaran Otomatisasi Tata Kelola Kepegawaian KD 3.8 Menerapkan Pengembangan Karir Pegawai dan KD 4.8 Mengelola Pengembangan Karir Pegawai (E-MOGA). 
Hasil uji coba kelayakan E-MOGA secara keseluruhan menurut ahli materi, ahli media, dan uji coba kelompok kecil adalah sangat valid dan layak digunakan sebagai bahan ajar dalam proses pembelajaran.

Bahan ajar Otomatisasi Tata Kelola Kepegawaian berupa E-Modul berbasis Flipbook efektif dalam meningkatkan hasil belajar peserta didik saat digunakan dalam kegiatan pembelajaran pada siswa kelas XI-OTKP di SMK Negeri 2 Blitar ditinjau dari rata-rata hasil belajar peserta didik kelas eksperimen yaitu 91,40 dan kelas kontrol yaitu 76,25. Dengan demikian diketahui bahwa nilai kognitif kelas kontrol < kelas eksperimen.

\section{Ucapan Terima Kasih}

Penulis mengucapkan terimakasih kepada Fakultas Ekonomi Universitas Negeri Malang dan SMK Negeri 2 Blitar yang telah memfasilitasi dan memberi izin kepada peneliti untuk melakukan kegiatan penelitian dan pengembangan ini.

\section{Daftar Rujukan}

Amaliyah, N., \& Puspasari, D. (2018). Pengembangan Media Pembelajaran Uno Card Pada Mata Pelajaran Administrasi Kepegawaian Kelas XI Administrasi Perkantoran Di SMKN 2 Buduran Sidoarjo. Jurnal Pendidikan Administrasi Perkantoran, 6(2), 102-110.

Asrial, Kurniawan, S. D. A., \& Anandari, Q. S. (2019). Digitalization of Ethno Constructivism Based Module for Elementary School Students. Jurnal Ilmu Pendidikan (JIP), 25(1), 33-41.

Diani, R., \& Hartati, N. S. (2018). Flipbook berbasis literasi Islam : Pengembangan media pembelajaran fisika dengan 3D pageflip professional. Jurnal Inovasi Pendidikan IPA, 4(2), 234-244.

Divayana, D. G. H., Ariawan, I. P. W., \& Suyasa, P. W. A. (2020). KKN-PM Berkonsep TAT TWAM ASI Pada desa Timpag Dalam Mewujudkan Desa Kolaboratif, Inovatif Dan Berbudaya. Jurnal Widya Laksana, 9(2), 189-204.

Ernawati, I., \& Sukardiyono, T. (2017). Uji Kelayakan Media Pembelajaran Interaktif Pada Mata Pelajaran Administrasi Server. Jurnal Elinvo, 2(2), 205-210.

Fitri, E. R. (2020). Pengembangan LKPD Berbantuan Kvisoft Flipbook Maker pada Mata Pelajaran Teknologi Perkantoran di SMKN 2 Nganjuk Pengembangan LKPD Berbantuan Kvisoft Flipbook Maker pada Mata Pelajaran Teknologi Perkantoran di SMKN 2 Nganjuk. JPAP: Jurnal Pendidikan Administrasi Perkantoran, 9(2), 281-291.

Fonda, A., \& Sumargiyani, S. (2018). The Developing Math Electronic Module With Scientific Approach Using Kvisoft Flipbook Maker Pro for Xi Grade of Senior High School Students. Infinity Journal, 7(2), 109. https://doi.org/10.22460/infinity.v7i2.p109-122

Hayati, S., Budi, A. S., \& Handoko, E. (2015). Pengembangan Media Pembelajaran Flipbook Fisika untuk Meningkatkan Hasil Belajar Peserta Didik. Prosiding Seminar Nasional Fisika (e-Jurnal) SNF2015, IV, 4954.

Hidyatullah, M. S., \& Rakhmawati, L. (2016). Pengembangan Media Pembelajaran Berbasis Flipbook Maker Pada Mata Pelajaran Elektronika Dasar Di SMK Negeri 1 Sampang. Jurnal Pendidikan Teknik Elektro, 5(1), 83-88.

Ismiarti, D. R., \& Nikmah, C. (2021). Pengembangan E-Modul Otomatisasi Tata Kelola Kepegawaian Berbasis Android Pada Materi Semester Gasal Kelas XI OTKP 2 di SMK PGRI 2 Sidoarjo. Jurnal Pendidikan Administrasi Perkantoran (JPAP), 9(1), 28-38.

Lestari, I. (2015). Pengaruh Waktu Belajar Dan Minat Belajar Terhadap Hasil Belajar Matematika. Jurnal Formatif, 3(2), 115-125.

Linda, R., Herdini, H., S, I. S., \& Putra, T. P. (2018). Interactive E-Module Development through Chemistry Magazine on Kvisoft Flipbook Maker Application for Chemistry Learning in Second Semester at Second Grade Senior High School. Journal of Science Learning, 2(1), 21. https://doi.org/10.17509/jsl.v2i1.12933

Meiristanti, N., \& Puspasari, D. (2020). Pengembangan Leaflet Berbasis Android sebagai Penunjang Bahan Ajar Pada Mata Pelajaran OTK Sarana dan Prasarana Kelas XI OTKP di SMK PGRI 2 Sidoarjo Pengembangan 
Leaflet Berbasis Android Sebagai Penunjang Bahan Ajar .... Jurnal Pendidikan Administrasi Perkantoran, $8(1), 56-67$.

Muslikhah, R. I., Siswandari, \& Murtini, W. (2016). Pengaruh Model Pembelajaran Quantum Teaching Berbantuan Flipbook Terhadap Hasil Belajar Ditinjau Dari Gaya Belajar Peserta Didik Pada Mata Pelajaran Pengantar Ekonomi Dan Bisnis. Jurnal Pendidikan Insan Mandiri, 1(9), 1-21.

Nurhasanah, S., \& Sobandi, A. (2016). Minat belajar sebagai determinan hasil belajar siswa. Jurnal Pendidikan Manajemen Perkantoran, 1(1), 128-135.

Nurseto, T. (2011). Membuat Media Pembelajaran yang Menarik. Jurnal Ekonomi \& Pendidikan, 8(1), 19-35.

Oktavira, R. A., \& Pahlevi, T. (2019). Pengembangan E-modul Berbantuan Kvisoft Flipbook Maker Berbasis Pendekatan Saintifik pada Materi Menerapkan Pengoperasian Aplikasi Pengolah Kata Kelas X OTKP 3 SMKN 2 Blitar. Jurnal Pendidikan Administrasi Perkantoran, 07, 60-65.

Ricu Sidiq, \& Najuah. (2020). Pengembangan E-Modul Interaktif Berbasis Android pada Mata Kuliah Strategi Belajar Mengajar. Jurnal Pendidikan Sejarah, 9(1), 1-14. https://doi.org/10.21009/jps.091.01

Rusman. (2013). Metode-Metode Pembelajaran: Mengembangkan Profesionalisme Guru. Jakarta: PT Raja Grafindo Persada.

Sudjana, N. (2013). Dasar-Dasar Proses Belajar Mengajar. Bandung: Sinar Baru.

Sugianto, D., Abdullah, A. G., Elvyanti, S., \& Muladi, Y. (2013). MODUL VIRTUAL : MULTIMEDIA FLIPBOOK DASAR TEKNIK DIGITAL Sugianto, D., Abdullah, A. G., Elvyanti, S., \& Muladi, Y. (2013). MODUL VIRTUAL : MULTIMEDIA FLIPBOOK DASAR TEKNIK DIGITAL. IX (2), 101-116. Jurnal INVOTEC, 9(2), 101-116.

Sugihartini, N., \& Jayanta, N. L. (2017). Pengembangan E-Modul Mata Kuliah Strategi Pembelajaran. Jurnal Pendidikan Teknologi Dan Kejuruan, 14(2), 221-230.

Sugiyono. (2011). Metode Penelitian Kuantitatif Kualitatif dan R\&D. Bandung: Alfabeta.

Sugiyono. (2012). Memahami Penelitian Kualitatif. Bandung: Alfabeta.

Sugiyono. (2015). Metode Penelitian Kombinasi. Bandung: Alfabeta.

Sukmawati, N. (2016). Pengembangan Flipbook Teks Eksplanasi Kompleks Untuk Peserta Didik Kelas XI SMA/MA Semester 2. Jurnal NOSI, 4(3), 243-253.

Supardi. (2013). Aplikasi Statistika Dalam Penelitian. Jakarta: Change Publication.

Syahroni, M., Nurrochmah, S., \& Amiq, F. (2016). PENGEMBANGAN BUKU SAKU ELEKTRONIK BERBASIS ANDROID TENTANG SIGNAL-SIGNAL WASIT FUTSAL UNTUK WASIT FUTSAL. Jurnal Pendidikan Jasmani, 26(02), 304-317.

Tim P2M LPPM UNS. (2010). Pengembangan E-Modul. Solo: LPPM UNS.

Wahyuni, S. (2015). Pengembangan Bahan Ajar IPA Untuk Meningkatkan Kemampuan Berpikir Kritis Siswa SMP. Jurnal Pengembangan Bahan Ajar IPA, 6(1), 300-305.

Wibowo, E., \& Pratiwi, D. D. (2018). Pengembangan Bahan Ajar Menggunakan Aplikasi Kvisoft Flipbook Maker Materi Himpunan. Desimal: Jurnal Matematika, 1(2), 147. https://doi.org/10.24042/djm.v1i2.2279.

Wibowo, M. H., \& Purnamasari, N. L. (2019). Pengaruh Media Pembelajaran Flip Book Terhadap Gaya Belajar Visual Siswa Kelas X Tkj Smkn 1 Boyolangu. JOEICT Journal of Education and Information Communication Technology), 3, 22-29.

Widiyaingtyas, T., \& Widiatmoko, A. (2014). Media Pembelajaran Berbasis Web Pada Mata Pelajaran Kimia. Jurnal Tekno, 21, 47-51.

Widodo, \& Widayanti, L. (2014). Peningkatan Aktivitas Belajar dan Hasil Belajar Siswa dengan Metode Problem Based Learning pada Siswa Kelas VII A MTs Negeri Donomulyo Kulon Progo Tahun Pelajaran 2012/2013. Jurnal Fisika Indonesia, 17(49), 32-35. https://doi.org/10.22146/jfi.24410.

Widyaningrum, P., \& Patrikha, F. D. (2021). Pengembangan E-Modul Dengan Flipbook Maker KD 3.6 Menganalisis Perilaku Konsumen Dalam Bisnis Ritel Kelas XI BDP Di SMK Negeri 2 Tuban. Jurnal Pendidikan Tata Niaga (JPTN), 9(1), 1048-1054.

Wijayanti, N. P. A., Damayanti, L. P. E., Sunarya, I. M. G., \& Putrama, I. M. (2016). PENGEMBANGAN E-MODUL BERBASIS PROJECT BASED LEARNING PADA MATA PELAJARAN SIMULASI DIGITAL UNTUK SISWA 
Jurnal Ekonomi, Bisnis dan Pendidikan, 1(6), 2021, 526-537

KELAS X STUDI KASUS DI SMK NEGERI 2 SINGARAJA. Jurnal Pendidikan Teknologi Dan Kejuruan, 13(2), 184-197.

Wijayanto, \& Zuhri, M. S. (2014). Pengembangan E-Modul Berbasis Flipbook Maker Dengan Model Project Based Learning Untuk Mengembangkan Kemampuan Pemecahan Masalah Matematika. Jurnal Pendidikan Matematika, 625-628.

Wulandari, Y., \& Purwanto, W. E. (2017). Kelayakan Aspek Materi dan Media Dalam Pengembangan Buku Ajar Sastra Lama. Jurnal Gramatika, 2, 162-172. 